Article

\title{
The Reaction Thermodynamics during Plating Al on Graphene Process
}

\author{
Zhanyong Zhao ${ }^{\circledR}$, Peikang Bai *, Liang Li, Jing Li, Liyun Wu, Pengcheng Huo and Le Tan \\ School of Materials Science and Engineering, North University of China, Taiyuan 030051, China; \\ syuzzy@126.com (Z.Z.); nucliliang@126.com (L.L.); jing.li3d@hotmail.com (J.L.); wuliyunnuc@126.com (L.W.); \\ nuchpc@126.com (P.H.); hltanle@foxmail.com (L.T.) \\ * Correspondence: baipeikang@nuc.edu.cn; Tel.: +86-0351-3921751
}

Received: 23 December 2018; Accepted: 18 January 2019; Published: 21 January 2019

check for updates

\begin{abstract}
This research explored a novel chemical reduction of organic aluminum for plating $\mathrm{Al}$ on a graphene surface. The thermodynamics of the Al plating reaction process were studied. The Al plating process consisted of two stages: the first was to prepare $\left(\mathrm{C}_{2} \mathrm{H}_{5}\right)_{3} \mathrm{Al}$. In this reaction, the $\Delta \mathrm{H}$ (enthalpy) was $10.64 \mathrm{kcal} / \mathrm{mol}$, the $\Delta \mathrm{G}$ (Gibbs free energy) was $19.87 \mathrm{kcal} / \mathrm{mol}$ and the $\Delta S$ (entropy) was $30.9 \mathrm{cal} /(\mathrm{mol} \cdot \mathrm{K})$; this was an endothermic reaction. In the second stage, the $\left(\mathrm{C}_{2} \mathrm{H}_{5}\right)_{3} \mathrm{Al}$ decomposed into $\mathrm{Al}$ atoms, which were gradually deposited on the surface of the graphene and the $\mathrm{Al}$ plating formed. At $298.15 \mathrm{~K}$, the $\Delta \mathrm{H}$ was $-20.21 \mathrm{kcal} / \mathrm{mol}$, the $\Delta \mathrm{G}$ was $-54.822 \mathrm{kcal} / \mathrm{mol}$, the $\Delta S$ was $116.08 \mathrm{cal} /(\mathrm{mol} \cdot \mathrm{K})$ and the enthalpy change was negative, thus indicating an endothermic reaction.
\end{abstract}

Keywords: density functional theory (DFT); thermodynamics; graphene/aluminum composites

\section{Introduction}

Graphene/aluminum composites have high strength, high conductivity and high toughness. Thus, graphene/aluminum composites have wide application potentiality in the electronics, automotive and aerospace industry [1-8]. However, graphene/aluminum composites are difficult to prepare; because of the poor wettability between $\mathrm{Al}$ and graphene, the graphene aggregates easily in the $\mathrm{Al}$ matrix, which can decrease the mechanical properties of the composites $[9,10]$. In order to improve the wettability between graphene and $\mathrm{Al}$, the ideal method is to coating melt on the surface of the graphene, by methods including self-assembly, chemical reduction, electrochemical deposition, redox method and chemical vapor deposition. For instance, Bagheri et al. prepared graphene-gold nanocomposites by self-assembly [11]. Tsai et al. coated the $\mathrm{Cu}$ nanoparticles on the graphene surface through coalescence and epitaxial self-assembly and studied molecular dynamics during the process [12]. Muszynski et al. synthesized gold nanoparticles through the chemical reduction of $\mathrm{AuCl}_{4}{ }^{-}$(Aldrich) with $\mathrm{NaBH}_{4}$ and coated the gold nanoparticles on the surface of graphene [13]. Zhao et al. prepared graphene nanoplatelets by reinforcing copper matrix composites with electrochemical deposition and the composites' hardness and conductivity reached $111.2 \mathrm{HV}$ and $89.2 \%$ IACS [14]. Kim et al. prepared single-atomic-layer graphene film on the surface of $\mathrm{Cu}$ through chemical vapor deposition (CVD), then obtained multi-layer graphene/copper composites with the strength of 1.5 GPa [15]. According to previous investigations, gold, copper, or nickel nanoparticles were usually coated on the graphene. However, these metal nanoparticles may be viewed as impurities in $\mathrm{Al}$ alloys, which can affect their properties. Plating $\mathrm{Al}$ on graphene is an effective method to improve graphene's wettability and reduce these impurities. Because the $\mathrm{Al}$ is active, it is difficult to displace $\mathrm{Al}$ atom from conventional $\mathrm{Al}$ salt solution [16].

Selective laser melting (SLM), through melting successive layers of metal powder, is a promising metal additive manufacturing method $[17,18]$, it has huge advantages compared to traditional 
processing methods [19-24] and therefore has been widely used in the fields of medical, military, aerospace and automobile manufacturing [25]. The purpose of this new method is to increase the weight of graphene by plating $\mathrm{Al}$ on its surface, which solves the problem of uneven dispersion of graphene in $\mathrm{Al}$ powder for SLM. Considering that plating $\mathrm{Al}$ on graphene is difficult, we explored a novel chemical reduction of organic aluminum for plating $\mathrm{Al}$ on the graphene surface [19]. The $\mathrm{Al}$ plating process consisted of two stages. In the first stage, the $\mathrm{Al}$ powders were added to the $\mathrm{C}_{2} \mathrm{H}_{5} \mathrm{Br}$ solution, to produce $\left(\mathrm{C}_{2} \mathrm{H}_{5}\right)_{3} \mathrm{Al}$. In the second stage, the $\left(\mathrm{C}_{2} \mathrm{H}_{5}\right)_{3} \mathrm{Al}$ decomposed into $\mathrm{Al}$ atoms, which were gradually deposited on the surface of the graphene and the Al plating formed [26]. The microstructure evolution was reported [26].

However, the reaction mechanism was unclear, especially the thermodynamics of the reaction process. Density functional theory (DFT) is a quantum mechanical method for studying the electronic structure of multi-electron systems [27-29]. DFT has a wide range of applications in physics and chemistry, especially for studying the properties of molecules and condensed states [30-32]. It is one of the most commonly used methods in computational materials and computational chemistry [30]. The objective of the study described here is to elucidate the thermodynamics of the Al plating reaction process and it provides guidance for process optimization.

\section{Experiment and Simulation}

\subsection{Experiment}

The $\mathrm{Al}$ powders and the graphene were employed as raw materials, as shown in Figure 1. During the $\mathrm{Al}$ plating reaction process, $\mathrm{H}_{2}$ gas was pumped into the reaction vessel and the $\mathrm{Al}$ powder $(1.5 \mathrm{~g})$, aluminum chloride $(0.1 \mathrm{~g})$ and iodine $(0.1 \mathrm{~g})$ were dried and added into the $\mathrm{C}_{2} \mathrm{H}_{5} \mathrm{Br}(29 \mathrm{~mL})$ at $39^{\circ} \mathrm{C}$. Al reacted with $\mathrm{C}_{2} \mathrm{H}_{5} \mathrm{Br}$ and the $\left(\mathrm{C}_{2} \mathrm{H}_{5}\right)_{2} \mathrm{AlBr}$ and $\mathrm{C}_{2} \mathrm{H}_{5} \mathrm{AlBr}_{2}$ were obtained as follows [26]:

$$
3 \mathrm{C}_{2} \mathrm{H}_{5} \mathrm{Br}+2 \mathrm{Al} \rightarrow\left(\mathrm{C}_{2} \mathrm{H}_{5}\right)_{2} \mathrm{AlBr}+\mathrm{C}_{2} \mathrm{H}_{5} \mathrm{AlBr}
$$

The $\mathrm{Al}$ reacted with $\mathrm{C}_{2} \mathrm{H}_{5} \mathrm{AlBr}_{2}$ to produce $\left(\mathrm{C}_{2} \mathrm{H}_{5}\right)_{2} \mathrm{AlBr}$, $\mathrm{Al}$ and $\mathrm{AlBr}_{3}$ [26]:

$$
2 \mathrm{C}_{2} \mathrm{H}_{5} \mathrm{AlBr}+\mathrm{Al} \rightarrow\left(\mathrm{C}_{2} \mathrm{H}_{5}\right)_{2} \mathrm{AlBr}+\mathrm{Al}+\mathrm{AlBr}_{3}
$$

The $\left(\mathrm{C}_{2} \mathrm{H}_{5}\right)_{2} \mathrm{AlBr}$ and $\mathrm{Al}$ further reacted to produce $\mathrm{Al},\left(\mathrm{C}_{2} \mathrm{H}_{5}\right)_{3} \mathrm{Al}$ and $\mathrm{AlBr}_{3}$ via Equation [26]:

$$
3\left(\mathrm{C}_{2} \mathrm{H}_{5}\right)_{2} \mathrm{AlBr}+\mathrm{Al} \rightarrow 2\left(\mathrm{C}_{2} \mathrm{H}_{5}\right)_{3} \mathrm{Al}+\mathrm{Al}+\mathrm{AlBr}_{3}
$$

After reaction, the solution temperature was kept at $0{ }^{\circ} \mathrm{C}$ for $1 \mathrm{~h}$. The tetrahydrofuran was added to the solution. The solution was filtered after the reaction and the alkyl aluminum solution was obtained. Then, the graphene $(0.05 \mathrm{~g})$ was added to the alkyl aluminum solution. The temperature was kept at $70-100{ }^{\circ} \mathrm{C}$ for $1-1.5 \mathrm{~h}$ and the $\left(\mathrm{C}_{2} \mathrm{H}_{5}\right)_{3} \mathrm{Al}$ was decomposed into $\mathrm{Al}, \mathrm{H}_{2}$ and $\mathrm{C}_{2} \mathrm{H}_{4}$ [26]:

$$
2\left(\mathrm{C}_{2} \mathrm{H}_{5}\right)_{3} \mathrm{Al} \rightarrow 6 \mathrm{C}_{2} \mathrm{H}_{4}+3 \mathrm{H}_{2}+2 \mathrm{Al}
$$

The $\mathrm{Al}$ atoms were gradually deposited on the surface of the graphene and the $\mathrm{Al}$ plating formed. $\mathrm{Al}$ atoms absorbed on graphene may form upon $\left(\mathrm{C}_{2} \mathrm{H}_{5}\right)_{3} \mathrm{Al} /$ graphene collisions. This reaction is initiated by ethane elimination from the $\left(\mathrm{C}_{2} \mathrm{H}_{5}\right)_{3} \mathrm{Al}$ molecule, similar to the observations reported for $\left(\mathrm{CH}_{3}\right)_{3} \mathrm{Al}$ /graphene [33].

Microstructure observation was carried out using a scanning electron microscope (SEM) (Zeiss Ultra 55, Carl Zeiss Microscopy, Jena, Germany) equipped with energy dispersive spectroscopy (EDS). 

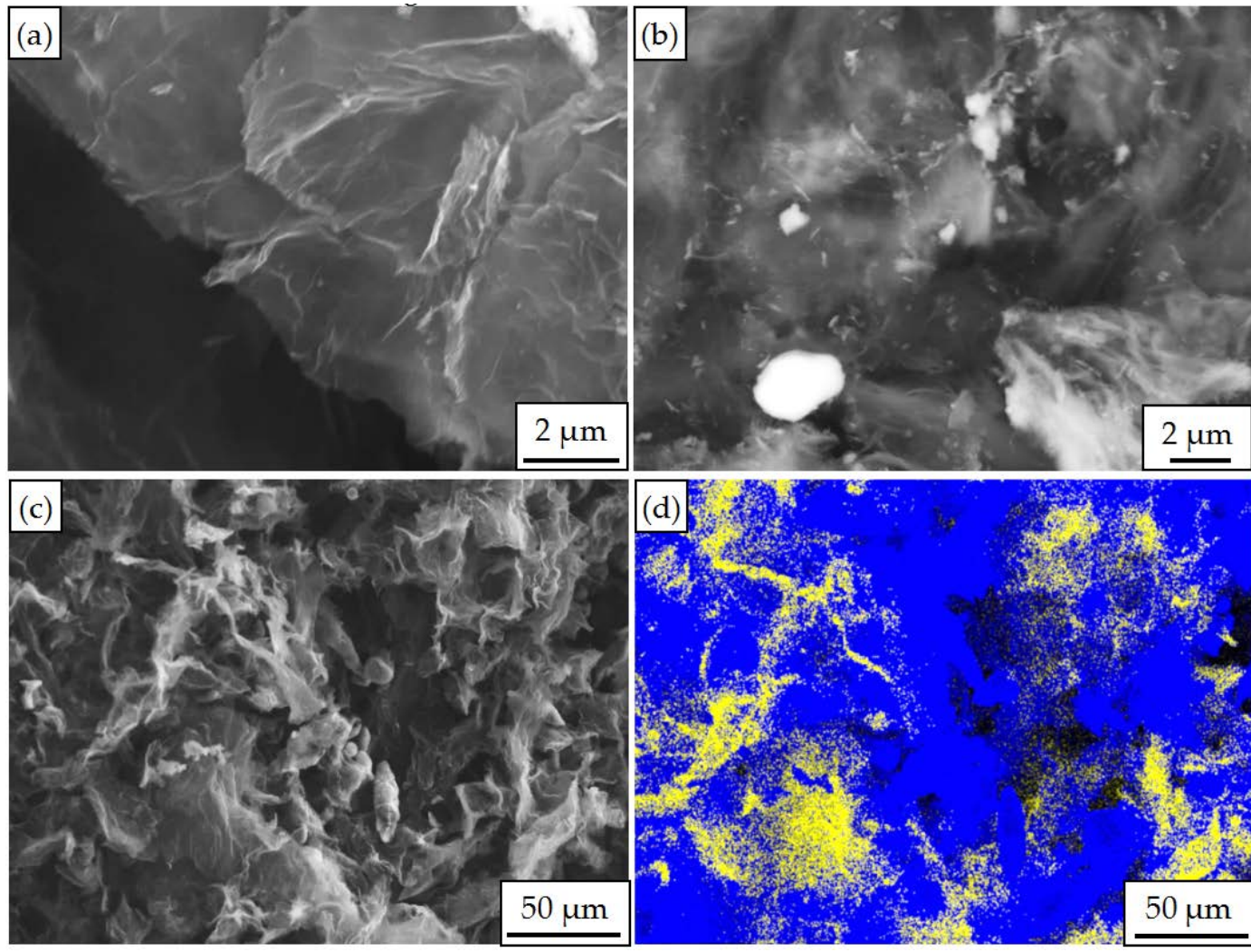

Figure 1. Scanning electron microscopy (SEM) image and energy dispersive spectrometer (EDS) analysis of Graphene/aluminum composites with different reaction times: (a) Graphene/aluminum composites prepared with reaction time of $1 \mathrm{~h}$; (b) Graphene/aluminum composites prepared with reaction time of $1.5 \mathrm{~h}$; (c) Low-magnification SEM image of composite prepared with reaction time of $1.5 \mathrm{~h}$; (d) map analysis of (c).

\subsection{Computation Details}

During the process of plating $\mathrm{Al}$ on the graphene, the thermodynamics of the chemical reduction of organic aluminum were simulated by density functional theory (DFT) methods implemented in the DMol3 package of Materials Studio. The structure of the reaction products was analyzed through the DFT, revealing the thermodynamic properties and reaction types of the chemical reactions. Spin-unrestricted DFT in the generalized gradient approximation (GGA) with the Revised Perdew-Burke-Eruzerhof (RPBE) exchange-correlation functional approach and double numerical plus polarization atomic orbitals was employed as the basis set. The Brillouin zone was sampled using the $4 \times 4 \times 1$ k-point grid thickness, which presented a good approximation of the model below the article. In addition, the energy tolerance accuracy, maximum force and displacement were set as $1 \times 10^{-5} \mathrm{Ha}$, $2 \times 10^{-3} \mathrm{Ha} / \AA$ and $5 \times 10^{-3} \AA$, respectively, to ensure high accuracy in all calculations.

During the Dmol3 simulation process, the relationship between thermodynamic properties (entropy S, enthalpy $\mathrm{H}$, heat capacity $\mathrm{Cp}$, Gibbs free energy $\mathrm{G}$ ) and temperature can be calculated from the vibration frequency. The total energy at $0 \mathrm{~K}$ was obtained during the simulation. The translational energy, rotational energy and vibration energy were used to calculate the thermodynamic properties at an instantaneous temperature. The instantaneous enthalpy $\mathrm{H}$ is:

$$
H(T)=E_{v i b}(T)+E_{\text {rot }}(T)+E_{\text {trans }}(T)+R T
$$

where $E_{\text {vib }}(T), E_{\text {rot }}(T)$ and $E_{\text {trans }}(T)$ are vibration energy, rotational energy and translational energy respectively at temperature $T$ and $R$ is an ideal gas constant. 
The contribution of vibration to enthalpy is:

$$
E_{v i b}(T)=\frac{R}{K} \frac{1}{2} \sum_{i} h v_{i}+\frac{R}{K} \sum_{i} \frac{h v_{i} \exp \left(-h v_{i} / k T\right)}{1-\exp \left(-h v_{i} / k T\right)}
$$

The contribution of vibration to entropy is:

$$
S_{v i b}=R \sum_{i} \frac{\left(h v_{i} / k T\right) \exp \left(-h v_{i} / k T\right)}{1-\exp \left(-h v_{i} / k T\right)}-R \sum_{i} \ln \left[1-\exp \left(-h v_{i} / k T\right)\right]
$$

The contribution of vibration to heat capacity at normal pressure is:

$$
C_{v i b}=R \sum_{i} \frac{\left(h v_{i} / k T\right)^{2} \exp \left(-h v_{i} / k T\right)}{\left[1-\exp \left(-h v_{i} / k T\right)\right]^{2}}
$$

where $k$ is the Boltzmann constant, $h$ is the Planck constant and $v_{i}$ is the vibration frequency of the $i$ th atom. Each of the chemical bond vibrational frequencies was calculated by DFT at $298.15 \mathrm{~K}$ and then assumed to remain constant with Temperature.

\section{Results and Discussions}

\subsection{Preparation and Reaction Mechanism of Al-Coated Graphene}

During the Al plating process, with the increase of reaction time, more Al was deposited on the graphene, as shown in Figure $1 \mathrm{a}, \mathrm{b}$. When the chemical reduction reaction was at $1.5 \mathrm{~h}$, abundant $\mathrm{Al}$ atoms were deposited on the graphene uniformly, the Al plating was formed and the content of the $\mathrm{Al}$ element was $71 \%$, as shown in Figure 1c,d.

\subsection{Reaction Thermodynamics during Plating Al on Graphene Process}

The molecular model of each substance was established and its structure optimized during the chemical reduction reaction process. The vibration frequency was calculated and the thermodynamic properties of each substance were analyzed. The thermodynamics of the formation and decomposition of $\left(\mathrm{C}_{2} \mathrm{H}_{5}\right)_{3} \mathrm{Al}$ were calculated according to the laws of thermodynamics.

During the process of plating Al on grapheme, based on the reaction Equations (1) and (3), the structural optimization and thermodynamic calculation of $\mathrm{C}_{2} \mathrm{H}_{5} \mathrm{Br},\left(\mathrm{C}_{2} \mathrm{H}_{5}\right)_{2} \mathrm{AlBr}, \mathrm{C}_{2} \mathrm{H}_{5} \mathrm{AlBr}_{2}$, $\left(\mathrm{C}_{2} \mathrm{H}_{5}\right)_{3} \mathrm{Al}$ and $\mathrm{AlBr}_{3}$ were carried out through the $\mathrm{Al}$ cluster $\left(\mathrm{Al}_{3}\right)$ molecular model [34].

\subsubsection{Structure Optimization and Thermodynamic Properties of $\mathrm{C}_{2} \mathrm{H}_{5} \mathrm{Br}$}

Figure 2 shows the structure of the $\mathrm{C}_{2} \mathrm{H}_{5} \mathrm{Br}$ molecule. The initial structure of the $\mathrm{C}_{2} \mathrm{H}_{5} \mathrm{Br}$ molecule built in MS is shown in Figure 2a; the stable molecular structure after structure optimization is shown in Figure $2 \mathrm{~b}$. After structure optimization, $\angle \mathrm{H}_{1} \mathrm{C}_{1} \mathrm{C}_{2}$ was reduced from $109.471^{\circ}$ to $108.747^{\circ}, \angle \mathrm{H}_{1} \mathrm{C}_{1} \mathrm{C}_{2}$ increased from $109.471^{\circ}$ to $111.590^{\circ}, \angle \mathrm{C}_{1} \mathrm{C}_{2} \mathrm{Br}$ increased from $109.469^{\circ}$ to $111.496^{\circ}$ and $\angle \mathrm{BrC}_{2} \mathrm{H}_{5}$ decreased from $109.472^{\circ}$ to $103.736^{\circ}$. The bond length of $\mathrm{H}_{1}-\mathrm{C}_{1}$ decreased from $1.14 \AA$ to $1.1 \AA$, the $\mathrm{C}_{1}-\mathrm{C}_{2}$ bond was reduced from $1.54 \AA$ to $1.517 \AA$, the $\mathrm{C}_{2}-\mathrm{Br}$ bond as increased from $1.91 \AA$ to $2.025 \AA$ and the $\mathrm{C}_{2}-\mathrm{H}_{5}$ bond was reduced from $1.14 \AA$ to $1.095 \AA$. During the structure optimization process, the bond angle and bond length of atoms tended to be stable through the vibration displacement and the total energy was gradually minimized.

Figure 3 shows the relationship between the thermodynamic properties (entropy $\mathrm{S}$, enthalpy $\mathrm{H}$, heat capacity $\mathrm{Cp}$, Gibbs free energy $\mathrm{G}$ ) of the $\mathrm{C}_{2} \mathrm{H}_{5} \mathrm{Br}$ and temperature was obtained through Equations (5)-(8). In the range of 25-1000 K, the enthalpy of the $\mathrm{C}_{2} \mathrm{H}_{5} \mathrm{Br}$ molecule had a linear relationship with the temperature and the enthalpy value increased with the increase of temperature. The heat capacity of $\mathrm{C}_{2} \mathrm{H}_{5} \mathrm{Br}$ gradually increased with the increase of temperature, although the free 
energy decreased. At $298.15 \mathrm{~K}$, the enthalpy, entropy, free energy and heat capacity of $\mathrm{C}_{2} \mathrm{H}_{5} \mathrm{Br}$ molecules were $43.533 \mathrm{kcal} / \mathrm{mol}, 68.433 \mathrm{cal} /(\mathrm{mol} \cdot \mathrm{K}), 15.174 \mathrm{cal} /(\mathrm{mol} \cdot \mathrm{K})$ and $23.127 \mathrm{kcal} / \mathrm{mol}$ respectively, as shown in Table 1.
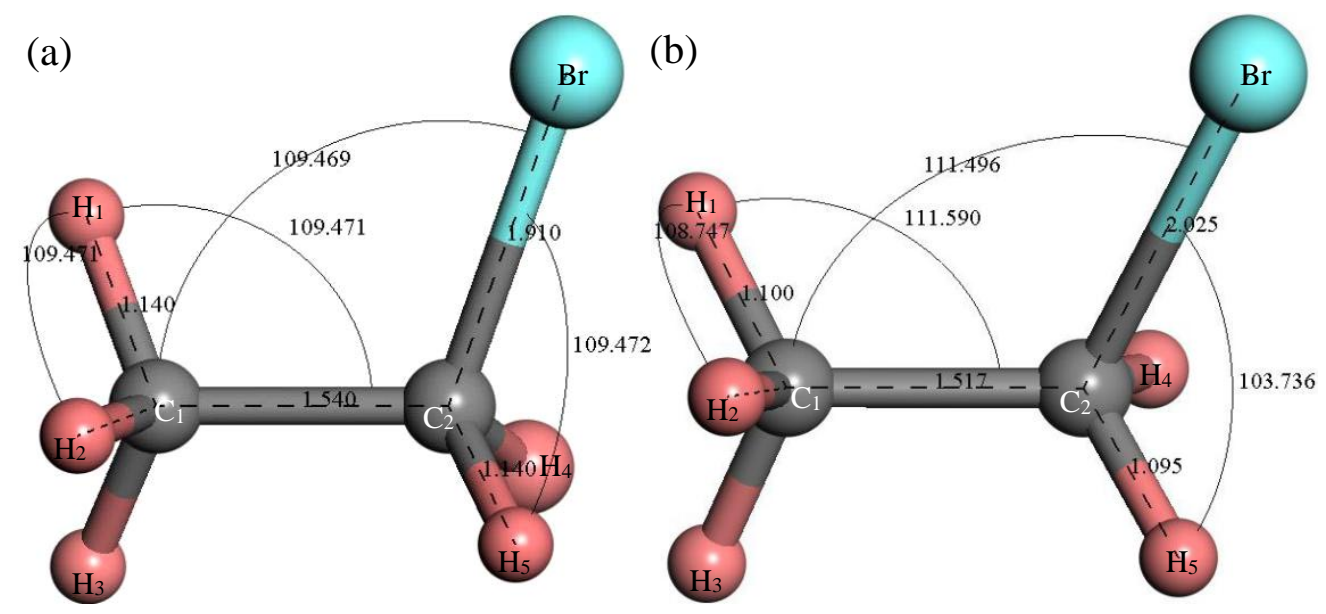

Figure 2. Molecular model of $\mathrm{C}_{2} \mathrm{H}_{5} \mathrm{Br}$ molecule. (a) Initial model; (b) Optimized model. The unit of the angle in the image is $\left({ }^{\circ}\right)$, and the unit of the bond length is angstrom $(\AA)$.

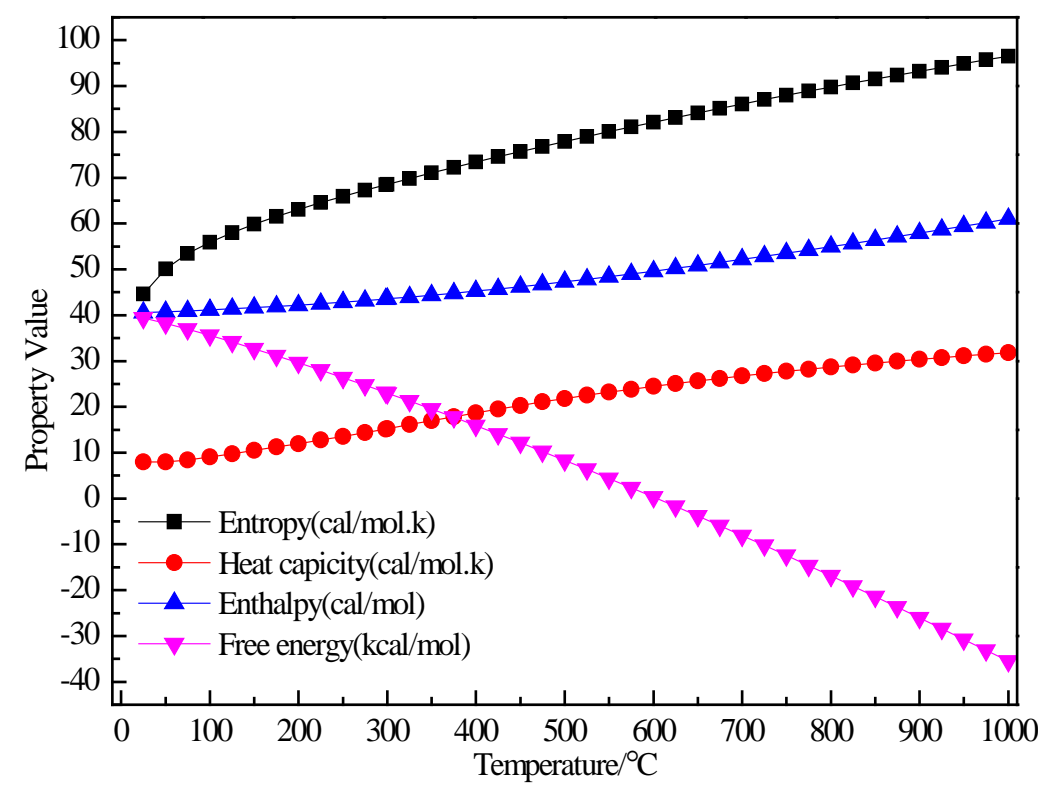

Figure 3. The relationship between the thermodynamic properties of $\mathrm{C}_{2} \mathrm{H}_{5} \mathrm{Br}$ and temperature.

Table 1. The total energy and the thermodynamic properties at $298.15 \mathrm{~K}$ of each component.

\begin{tabular}{cccc}
\hline Substance & E ( ${ }^{\mathbf{1}}$ Har/at) & H (kcal/mol) & G (kcal/mol) \\
\hline $\mathrm{C}_{2} \mathrm{H}_{5} \mathrm{Br}$ & -423.7794203 & 43.533 & 23.127 \\
$\mathrm{Al}$ & -727.1831592 & 4.348 & -16.613 \\
$\left(\mathrm{C}_{2} \mathrm{H}_{5}\right)_{2} \mathrm{AlBr}$ & -745.5311183 & 85.548 & 56.435 \\
$\mathrm{C}_{2} \mathrm{H}_{5} \mathrm{AlBr}_{2}$ & -1010.8496025 & 46.425 & 18.226 \\
\hline
\end{tabular}

${ }^{1} 1 \mathrm{Har} / \mathrm{at}=627.5 \mathrm{kcal} / \mathrm{mol}$.

\subsubsection{Structure Optimization and Thermodynamic Properties of $\left(\mathrm{C}_{2} \mathrm{H}_{5}\right)_{2} \mathrm{AlBr}$}

Figure 4 shows the structure of $\left(\mathrm{C}_{2} \mathrm{H}_{5}\right)_{2} \mathrm{AlBr}$. After structure optimization, $\angle \mathrm{H}_{1} \mathrm{C}_{1} \mathrm{H}_{2}$ decreased from $109.415^{\circ}$ to $107.039^{\circ}, \angle \mathrm{C}_{1} \mathrm{C}_{2} \mathrm{Al}$ increased by $9.965^{\circ}, \angle \mathrm{H}_{4} \mathrm{C}_{2} \mathrm{H}_{5}$ decreased by $5.254^{\circ}$ and $\angle \mathrm{C}_{2} \mathrm{AlC}_{3}$ 
increased by $2.571^{\circ}$. The length of the $\mathrm{Br}-\mathrm{Al}$ bond increased from $2.250 \AA$ to $2.331 \AA$, the length of the $\mathrm{Al}-\mathrm{C}_{3}$ bond increased from $1.88 \AA$ to $1.98 \AA$, the length of the $\mathrm{C}_{3}-\mathrm{H}_{7}$ bond decreased by $0.03 \AA$, the length of the $\mathrm{C}_{3}-\mathrm{C}_{4}$ bond increased by $0.009 \AA$ and the length of the $\mathrm{C}_{4}-\mathrm{H}_{9}$ bond decreased from $1.140 \AA$ to $1.102 \AA$. Figure 5 shows the relationship between the thermodynamic properties of $\left(\mathrm{C}_{2} \mathrm{H}_{5}\right)_{2} \mathrm{AlBr}$ and temperature. It can be seen that the enthalpy, entropy and heat capacity of $\left(\mathrm{C}_{2} \mathrm{H}_{5}\right)_{2} \mathrm{AlBr}$ increased with the increase of temperature in the range of 25-1000 K and the free energy decreased with the increase of temperature. At $298.15 \mathrm{~K}$, the enthalpy, entropy, heat capacity and free energy were $85.548 \mathrm{kcal} / \mathrm{mol}, 97.648 \mathrm{cal} /(\mathrm{mol} \cdot \mathrm{K}), 33.078 \mathrm{cal} /(\mathrm{mol} \cdot \mathrm{K})$ and $56.435 \mathrm{kcal} / \mathrm{mol}$, respectively, as shown in Table 1.

(a)

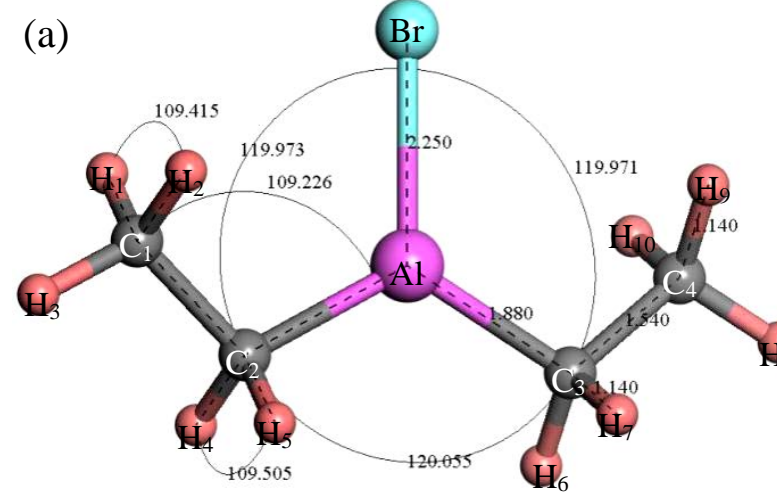

(b)

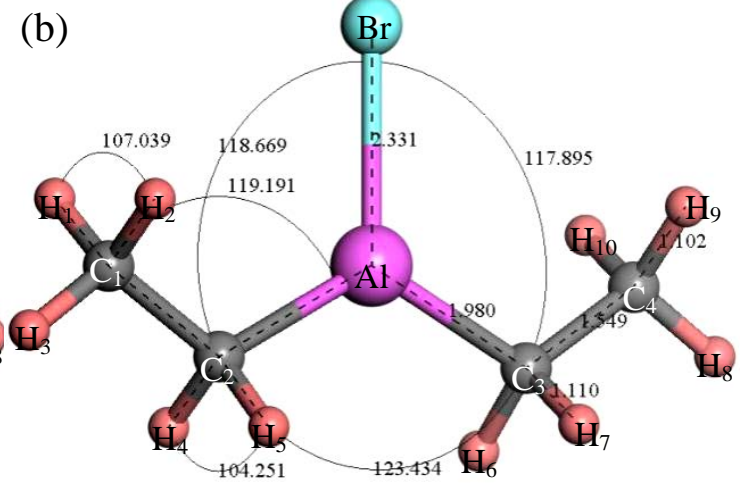

Figure 4. Molecular model of $\left(\mathrm{C}_{2} \mathrm{H}_{5}\right)_{2} \mathrm{AlBr}$ molecule. (a) Initial model; (b) Optimized model. The unit of the angle in the image is $\left(^{\circ}\right)$, and the unit of the bond length is angstrom $(\AA)$.

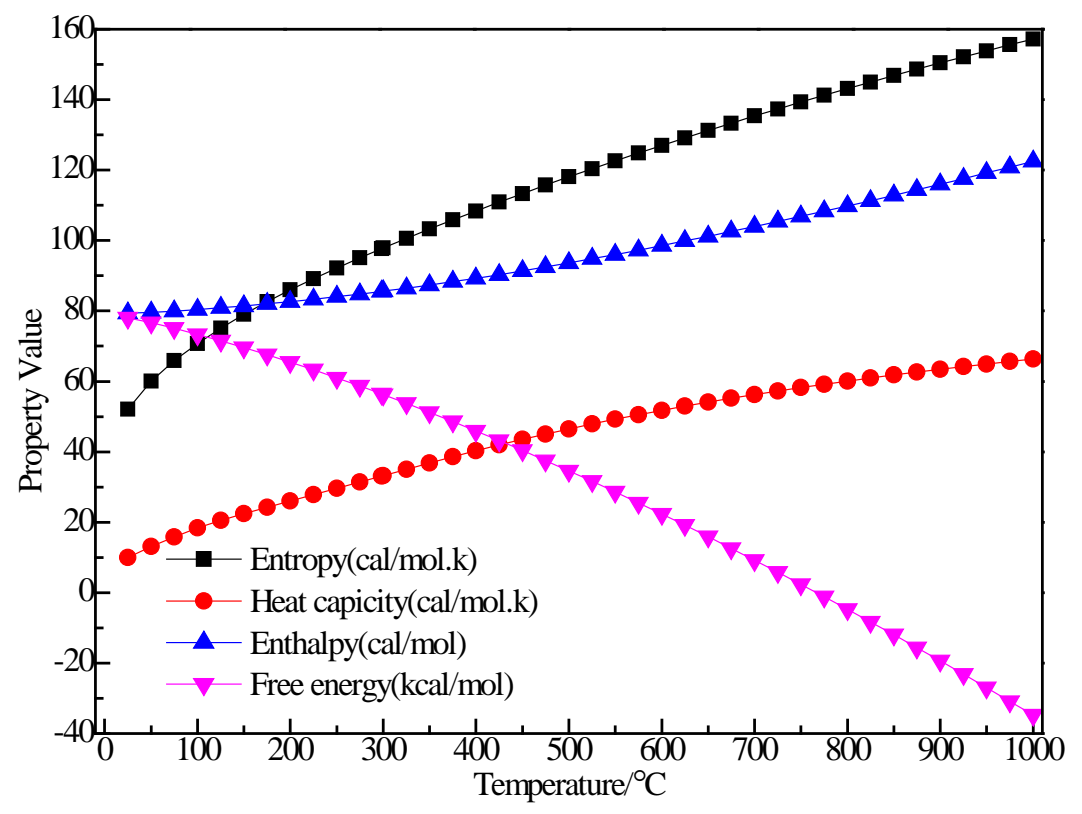

Figure 5. The relationship between the thermodynamic properties of $\left(\mathrm{C}_{2} \mathrm{H}_{5}\right)_{2} \mathrm{AlBr}$ and temperature.

\subsubsection{Structure Optimization and Thermodynamic Properties of $\mathrm{C}_{2} \mathrm{H}_{5} \mathrm{AlBr}_{2}$}

Figure 6 shows the original and the optimal structure of $\mathrm{C}_{2} \mathrm{H}_{5} \mathrm{AlBr}_{2}$. After structure optimization, $\angle \mathrm{H}_{1} \mathrm{C}_{1} \mathrm{H}_{2}$ decreased from $109.511^{\circ}$ to $104.953^{\circ}, \angle \mathrm{H}_{3} \mathrm{C}_{2} \mathrm{H}_{4}$ decreased from $109.52^{\circ}$ to $107.514^{\circ}, \angle \mathrm{C}_{2} \mathrm{C}_{1} \mathrm{Al}$ increased from $109.239^{\circ}$ to $117.439^{\circ}, \angle \mathrm{C}_{1} \mathrm{AlBr}_{1}$ increased by $0.3^{\circ}$ and $\angle \mathrm{Br}_{2} \mathrm{AlBr}_{1}$ decreased by $3.685^{\circ}$. The bond length of $\mathrm{H}_{2}-\mathrm{C}_{1}$ decreased from $1.14 \AA$ to $1.102 \AA$ and the bond length of $\mathrm{C}_{1}-\mathrm{C}_{2}$ increased by $0.007 \AA$, indicating that the $\mathrm{C}-\mathrm{C}$ bond was relatively stable. The bond length of $\mathrm{C}_{1}-\mathrm{Al}$ was increased by $0.085 \AA$ and the bond length of $\mathrm{Al}-\mathrm{Br}_{1}$ was increased by $0.45 \AA$. Figure 7 shows the relationship 
between the thermodynamic properties of $\mathrm{C}_{2} \mathrm{H}_{5} \mathrm{AlBr}_{2}$ and temperature. It can be seen that the enthalpy, entropy and heat capacity of $\mathrm{C}_{2} \mathrm{H}_{5} \mathrm{AlBr}_{2}$ increased with the increase of temperature in the range of 25-1000 K. The free energy decreased with the increase of temperature. At $298.15 \mathrm{~K}$, the enthalpy, entropy, heat capacity and free energy were $46.425 \mathrm{kcal} / \mathrm{mol}, 94.579 \mathrm{cal} /(\mathrm{mol} \cdot \mathrm{K}), 26.606 \mathrm{cal} /(\mathrm{mol} \cdot \mathrm{K})$ and $18.226 \mathrm{kcal} / \mathrm{mol}$ respectively (Table 1 ).
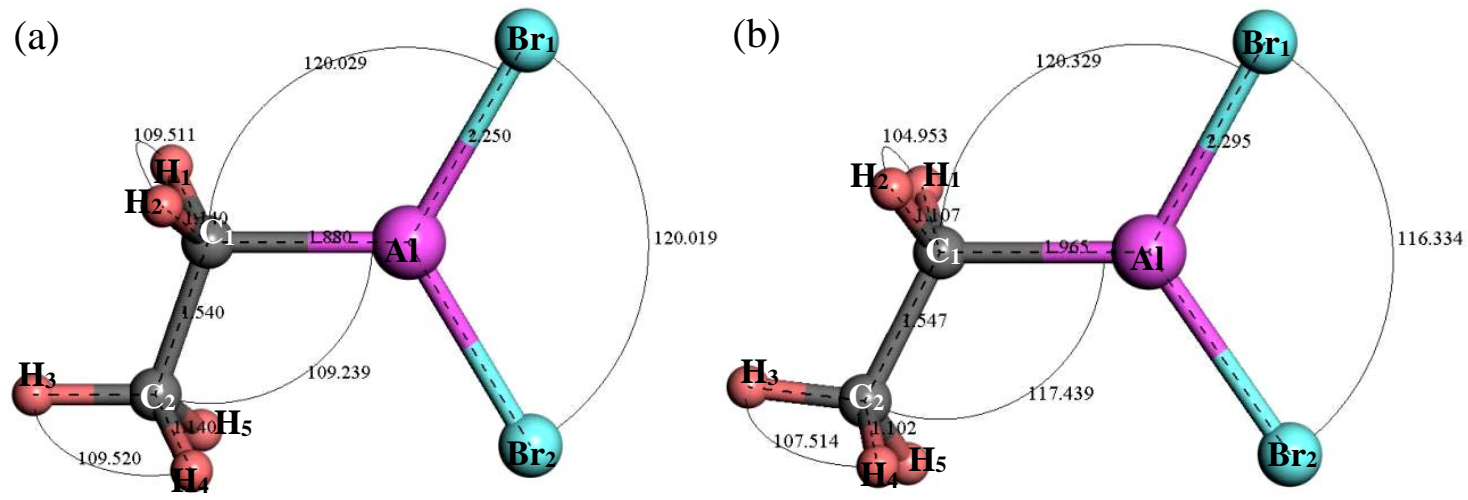

Figure 6. Molecular model of $\mathrm{C}_{2} \mathrm{H}_{5} \mathrm{AlBr}_{2}$ molecule. (a) Initial model; (b) Optimized model. The unit of the angle in the image is $\left(^{\circ}\right)$, and the unit of the bond length is angstrom $(\AA)$.

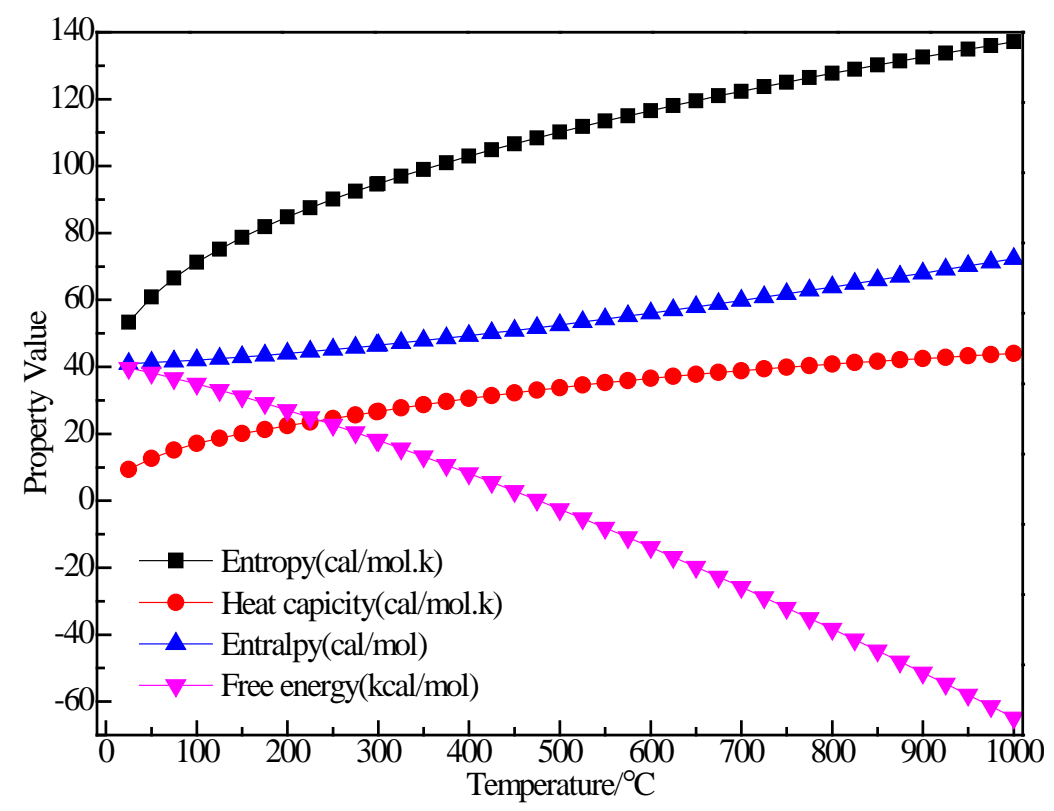

Figure 7. The relationship between the thermodynamic properties of $\mathrm{C}_{2} \mathrm{H}_{5} \mathrm{AlBr}_{2}$ and temperature.

\subsubsection{Structure Optimization and Thermodynamic Properties of $\left(\mathrm{C}_{2} \mathrm{H}_{5}\right)_{3} \mathrm{Al}$}

Figure 8 shows the structure of $\left(\mathrm{C}_{2} \mathrm{H}_{5}\right)_{3} \mathrm{Al}$. After structure optimization, $\angle \mathrm{C}_{2} \mathrm{AlC}_{3}$ was reduced from $119.992^{\circ}$ to $118.949^{\circ}, \angle \mathrm{C}_{2} \mathrm{AlC}_{5}$ decreased from $119.805^{\circ}$ to $119.593^{\circ}, \angle \mathrm{C}_{3} \mathrm{AlC}_{5}$ increased from $119.891^{\circ}$ to $121.407^{\circ}, \angle \mathrm{AlC}_{5} \mathrm{C}_{6}$ increased from $108.858^{\circ}$ to $117.775^{\circ}, \angle \mathrm{H}_{11} \mathrm{C}_{5} \mathrm{H}_{12}$ decreased from $109.536^{\circ}$ to $103.956^{\circ}$ and $\angle \mathrm{H}_{13} \mathrm{C}_{6} \mathrm{H}_{14}$ decreased from $109.444^{\circ}$ to $107.13^{\circ}$. The $\mathrm{H}_{1}-\mathrm{C}_{1}$ bond length was reduced from $1.14 \AA$ to $1.105 \AA$, the $C_{1}-C_{2}$ bond length increased from $1.54 \AA$ to $1.551 \AA$, the $C_{2}-A 1$ bond length increased from $1.879 \AA$ to $1.997 \AA$ and the $\mathrm{C}_{2}-\mathrm{H}_{4}$ bond length was reduced from $1.14 \AA$ to $1.112 \AA$. During the optimization process, the $\mathrm{C}-\mathrm{Al}$ bond rotated, the bond angle had large variation, the bond length changed little and the initial structure was significantly different from the optimized structure. Figure 9 shows the thermodynamic properties of $\left(\mathrm{C}_{2} \mathrm{H}_{5}\right)_{3} \mathrm{Al}$. In the range of $25-1000 \mathrm{~K}$, the enthalpy, entropy and heat capacity of $\left(\mathrm{C}_{2} \mathrm{H}_{5}\right)_{3} \mathrm{Al}$ increased with the increase of temperature. The free energy 
decreased with the increase of temperature. At $298.15 \mathrm{~K}$, the enthalpy, entropy and heat capacity were $125.294 \mathrm{kcal} / \mathrm{mol}, 102.836 \mathrm{cal} /(\mathrm{mol} \cdot \mathrm{K}), 41.264 \mathrm{cal} /(\mathrm{mol} \cdot \mathrm{K})$ and $94.634 \mathrm{kcal} / \mathrm{mol}$, respectively.
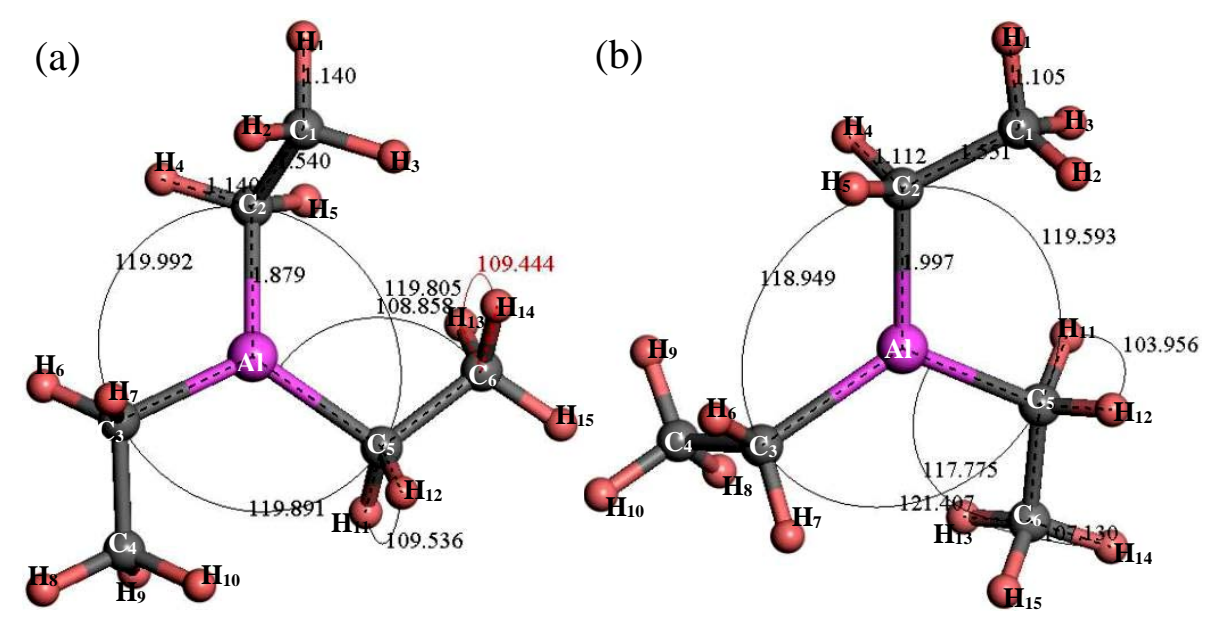

Figure 8. Molecular model of $\left(\mathrm{C}_{2} \mathrm{H}_{5}\right)_{3} \mathrm{Al}$ molecule. (a) Initial model; (b) Optimized model. The unit of the angle in the image is $\left(^{\circ}\right)$, and the unit of the bond length is angstrom $(\AA)$.

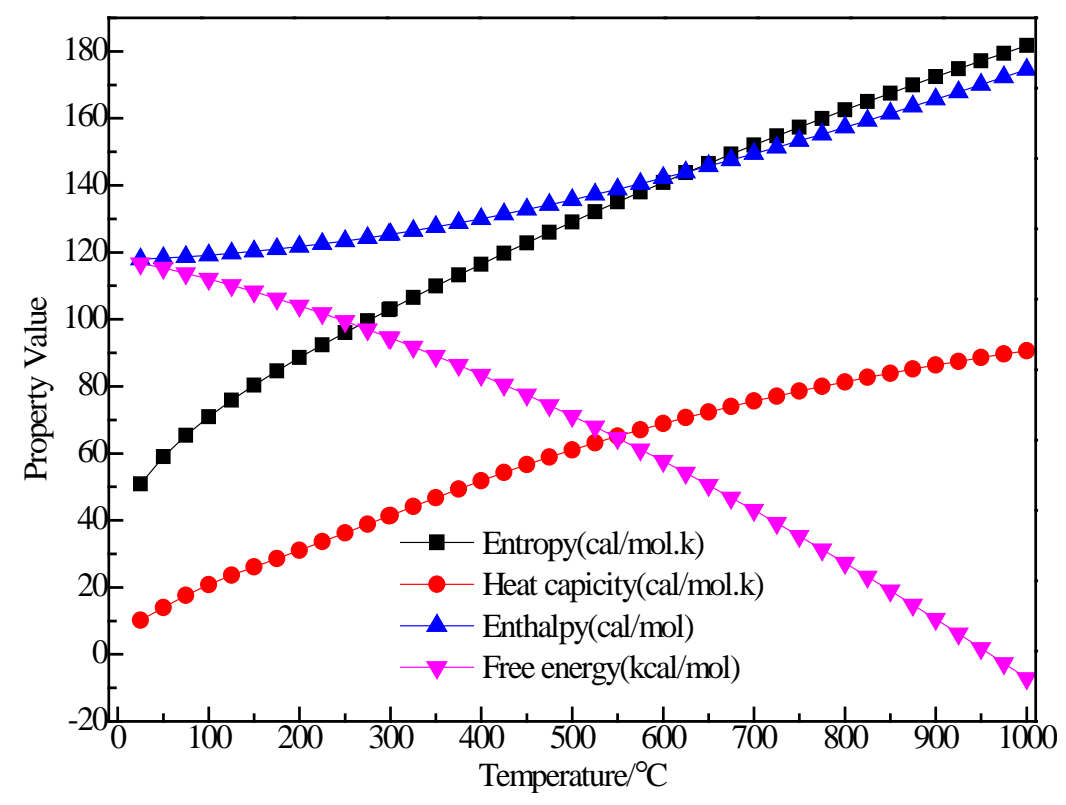

Figure 9. The relationship between the thermodynamic properties of $\left(\mathrm{C}_{2} \mathrm{H}_{5}\right)_{3} \mathrm{Al}$ and temperature.

\subsubsection{Structure Optimization and Thermodynamic Properties of $\mathrm{AlBr}_{3}$}

Figure 10 shows the structure of $\mathrm{AlBr}_{3}$. It can be seen that after optimization of the $\mathrm{AlBr}_{3}$ structure, the bond angle of $\mathrm{AlBr}_{3}$ increased from equal $120^{\circ}$ to $120.687^{\circ}, 120.173^{\circ}$ and $119.14^{\circ}$. $\mathrm{The} \mathrm{Br}_{1}-\mathrm{Al}$ bond length increased from $2.25 \AA$ to $2.264 \AA$, the $\mathrm{Br}_{2}-\mathrm{Al}$ bond length increased from $2.254 \AA$ to $2.264 \AA$ and the $\mathrm{Br}_{3}-\mathrm{Al}$ bond length increased from $2.25 \AA$ to $2.267 \AA$. Figure 11 shows the thermodynamic properties of $\mathrm{AlBr}_{3}$. It can be seen that in the range of $25-1000 \mathrm{~K}$, the enthalpy and entropy of the $\mathrm{AlBr}_{3}$ molecule increased with the increase of temperature, the heat capacity tended to be stable with the increase of temperature and the free energy decreased with the increase of temperature. The free energy was $0 \mathrm{kcal} / \mathrm{mol}$ at $25 \mathrm{~K}$, which gradually decreased to a negative value with the increase of temperature. At $298.15 \mathrm{~K}$, the enthalpy, entropy, heat capacity and free energy were $6.478 \mathrm{kcal} / \mathrm{mol}$, $88.04 \mathrm{cal} /(\mathrm{mol} \cdot \mathrm{K}), 18.250 \mathrm{cal} /(\mathrm{mol} \cdot \mathrm{K})$ and $-19.771 \mathrm{kcal} / \mathrm{mol}$, respectively. 

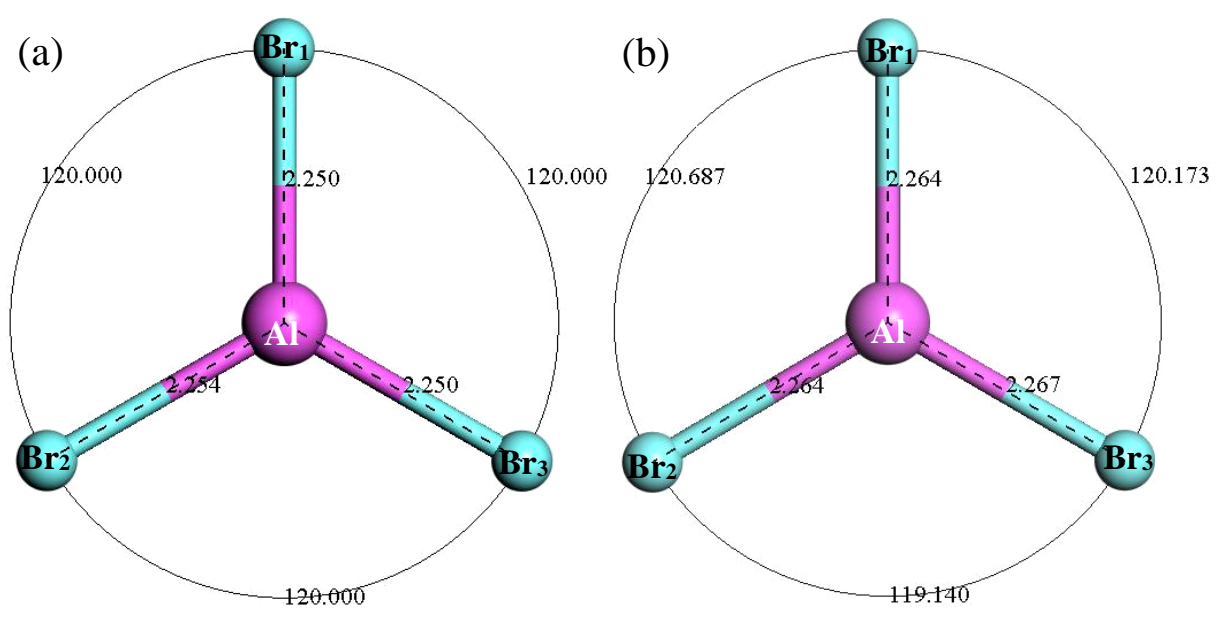

Figure 10. Molecular model of $\mathrm{AlBr}_{3}$ molecule. (a) Initial model; (b) Optimized model. The unit of the angle in the image is $\left(^{\circ}\right)$, and the unit of the bond length is angstrom $(\AA)$.

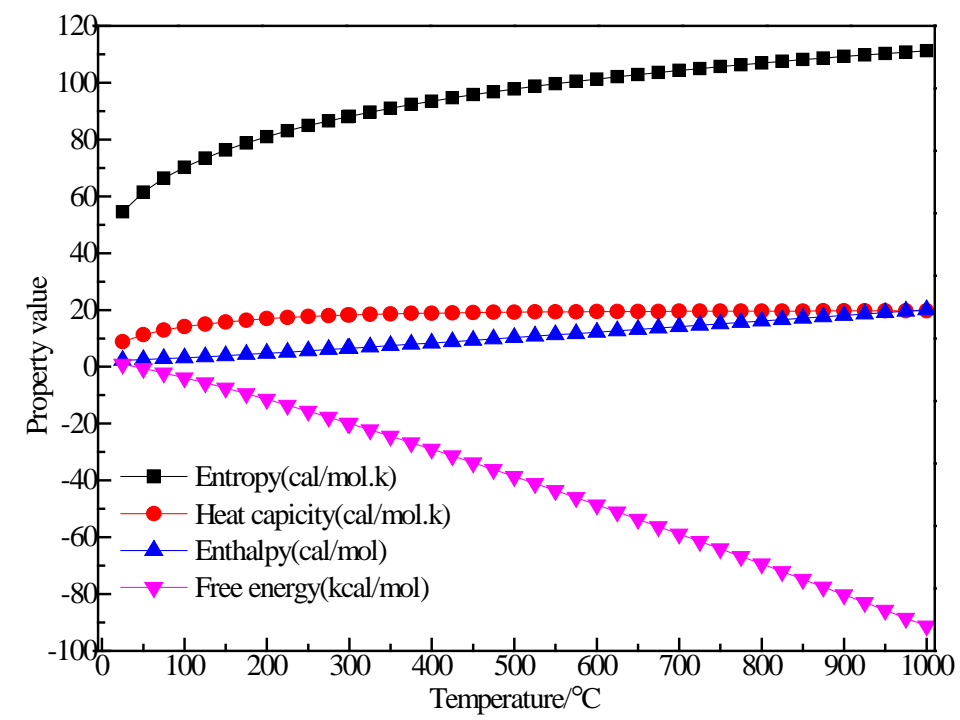

Figure 11. The relationship between the thermodynamic properties of $\mathrm{AlBr}_{3}$ and temperature.

Table 2 shows the thermodynamic properties during $\mathrm{Al}$ reacting with $\mathrm{C}_{2} \mathrm{H}_{5} \mathrm{Br}$ to produce $\left(\mathrm{C}_{2} \mathrm{H}_{5}\right)_{2} \mathrm{AlBr}$ and $\mathrm{C}_{2} \mathrm{H}_{5} \mathrm{AlBr}_{2}$. It can be seen that when the reaction temperature was $298.15 \mathrm{~K}$, the $\Delta \mathrm{H}$ was $-160.77 \mathrm{kcal} / \mathrm{mol}, \Delta \mathrm{G}$ was $-139.83 \mathrm{kcal} / \mathrm{mol}$ and $\Delta \mathrm{S}$ was $-70.2 \mathrm{cal} /(\mathrm{mol} \cdot \mathrm{K})$; it was thus an exothermic reaction.

Table 2. The thermodynamic properties during $\mathrm{Al}$ reacting with $\mathrm{C}_{2} \mathrm{H}_{5} \mathrm{Br}$ to produce $\left(\mathrm{C}_{2} \mathrm{H}_{5}\right)_{2} \mathrm{AlBr}$ and $\mathrm{C}_{2} \mathrm{H}_{5} \mathrm{AlBr}_{2}$.

\begin{tabular}{|c|c|c|}
\hline${ }^{1} \Delta \mathrm{H}(\mathrm{kcal} / \mathrm{mol})$ & ${ }^{2} \Delta \mathrm{G}(\mathrm{kcal} / \mathrm{mol})$ & ${ }^{3} \Delta \mathrm{S}(\mathrm{cal} / \mathrm{mol} \cdot \mathrm{K})$ \\
\hline-160.77 & -139.83 & -70.2 \\
\hline
\end{tabular}

Table 3 shows the total energy and thermodynamic properties of each component during $\left(\mathrm{C}_{2} \mathrm{H}_{5}\right)_{3} \mathrm{Al}$ preparation at $298.15 \mathrm{~K}$. Table 4 shows the thermodynamic properties during the $\left(\mathrm{C}_{2} \mathrm{H}_{5}\right)_{3} \mathrm{Al}$ preparation process (reaction Equation (3)). At $298.15 \mathrm{~K}$, the $\Delta \mathrm{H}$ was $10.64 \mathrm{kcal} / \mathrm{mol}$, the $\Delta \mathrm{G}$ was $19.87 \mathrm{kcal} / \mathrm{mol}$, the $\Delta \mathrm{S}$ was $30.9 \mathrm{cal} /(\mathrm{mol} \cdot \mathrm{K})$ and the enthalpy change was greater than 0 ; indicating this was an endothermic reaction. 
Table 3. Total energy and thermodynamic properties of each component during $\left(\mathrm{C}_{2} \mathrm{H}_{5}\right)_{3} \mathrm{Al}$ preparation at $298.15 \mathrm{~K}$.

\begin{tabular}{cccc}
\hline Substance & E (Har/at) & H (kcal/mol) & G (kcal/mol) \\
\hline$\left(\mathrm{C}_{2} \mathrm{H}_{5}\right)_{3} \mathrm{Al}$ & -480.2022142 & 125.294 & 94.634 \\
$\mathrm{AlBr}_{3}$ & -1276.1579299 & 6.478 & -19.771 \\
\hline
\end{tabular}

Table 4. The thermodynamic properties during preparing $\left(\mathrm{C}_{2} \mathrm{H}_{5}\right)_{3} \mathrm{Al}$ process.

\begin{tabular}{ccc}
\hline$\Delta \mathbf{H}(\mathrm{kcal} / \mathrm{mol})$ & $\Delta \mathrm{G}(\mathrm{kcal} / \mathrm{mol})$ & $\Delta \mathbf{S ~}(\mathrm{cal} / \mathbf{m o l} \cdot \mathbf{K})$ \\
\hline 10.64 & 19.87 & 30.9 \\
\hline
\end{tabular}

\subsubsection{Structure Optimization and Thermodynamic Properties of $\mathrm{C}_{2} \mathrm{H}_{4}$}

Figure 12 shows the structure of $\mathrm{C}_{2} \mathrm{H}_{4}$. After structural optimization, $\angle \mathrm{H}_{2} \mathrm{C}_{2} \mathrm{H}_{4}$ was reduced from $120.001^{\circ}$ to $116.504^{\circ}$. The bond length of $\mathrm{C}-\mathrm{H}$ decreased from $1.14 \AA$ to $1.094 \AA$ and the bond length of $\mathrm{C}=\mathrm{C}$ was reduced from $1.54 \AA$ to $1.342 \AA$. Figure 13 shows the thermodynamic properties of $\mathrm{C}_{2} \mathrm{H}_{4}$. It can be seen that the enthalpy, entropy and heat capacity of $\mathrm{C}_{2} \mathrm{H}_{4}$ increased with the increase of temperature in the range of 25-1000 K. The free energy decreased with the increase of temperature. At $298.15 \mathrm{~K}$, the enthalpy, entropy, heat capacity and free energy were $33.759 \mathrm{kcal} / \mathrm{mol}$, $55.228 \mathrm{cal} /(\mathrm{mol} \cdot \mathrm{K}), 10.372 \mathrm{cal} /(\mathrm{mol} \cdot \mathrm{K})$ and $17.293 \mathrm{kcal} / \mathrm{mol}$ respectively (Table 5).
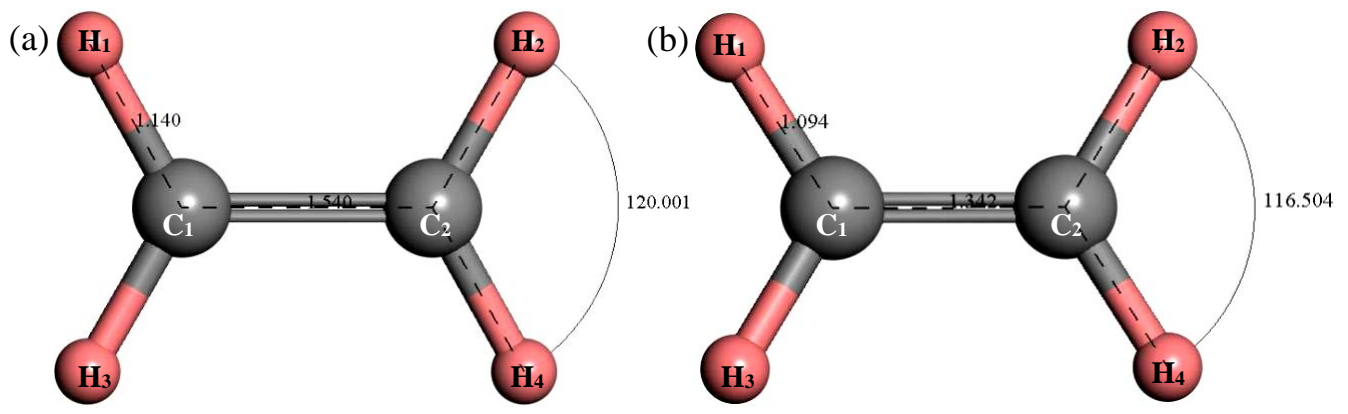

Figure 12. Molecular model of $\mathrm{C}_{2} \mathrm{H}_{4}$ molecule. (a) Initial model; (b) Optimized model. The unit of the angle in the image is $\left(^{\circ}\right)$, and the unit of the bond length is angstrom $(\AA)$.

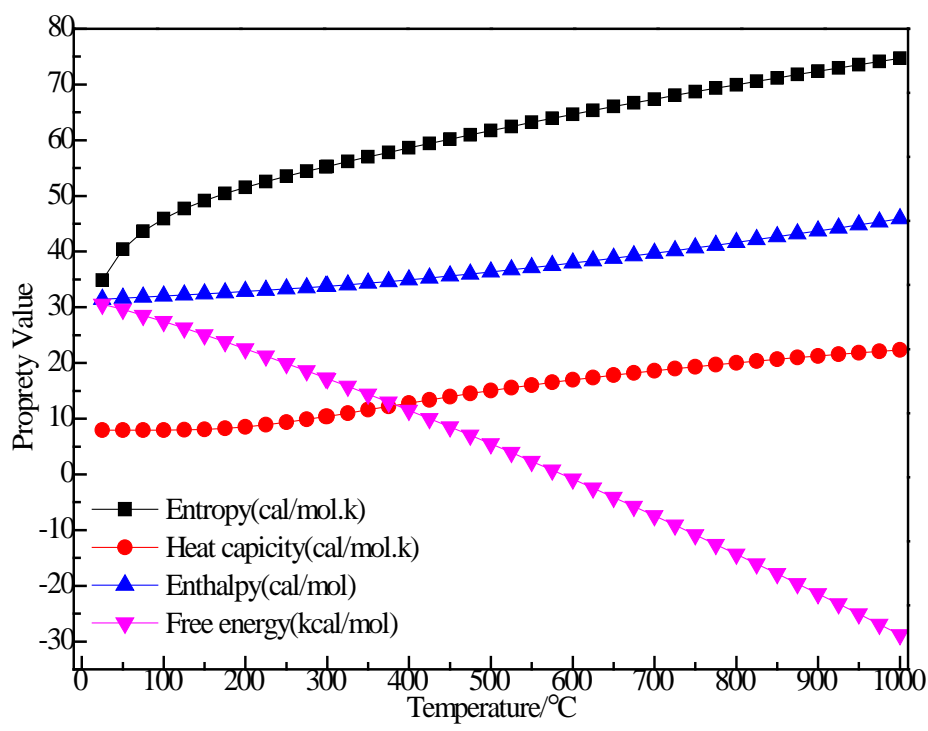

Figure 13. The relationship between the thermodynamic properties of $\mathrm{C}_{2} \mathrm{H}_{4}$ and temperature. 
Table 5. The total energy and thermodynamic properties of each component during $\left(\mathrm{C}_{2} \mathrm{H}_{5}\right)_{3} \mathrm{Al}$ decomposition at $298.15 \mathrm{~K}$.

\begin{tabular}{cccc}
\hline Substance & E (Har/at) & H (kcal/mol) & G (kcal/mol) \\
\hline $\mathrm{C}_{2} \mathrm{H}_{4}$ & -78.6243401 & 33.759 & 17.293 \\
$\mathrm{H}_{2}$ & -1.2899789 & 8.367 & -1.332 \\
\hline
\end{tabular}

\subsubsection{Structure Optimization and Thermodynamic Properties of $\mathrm{H}_{2}$}

Figure 14 shows the structure of $\mathrm{H}_{2}$. It can be seen that after structural optimization, the bond length of $\mathrm{H}-\mathrm{H}$ increased from $0.74 \AA$ to $0.747 \AA$. Figure 15 shows the relationship between the thermodynamic properties of $\mathrm{H}_{2}$ and temperature. The enthalpy, entropy and heat capacity of $\mathrm{H}_{2}$ increased with the increase of temperature and the free energy decreased with the increase of temperature. At $298.15 \mathrm{k}$, the enthalpy, entropy, heat capacity and free energy were respectively $8.367 \mathrm{cal} / \mathrm{mol}, 32.531 \mathrm{cal} /(\mathrm{mol} \cdot \mathrm{K}), 6.955 \mathrm{cal} /(\mathrm{mol} \cdot \mathrm{K})$ and $-1.332 \mathrm{kcal} / \mathrm{mol}$ (Table 5).
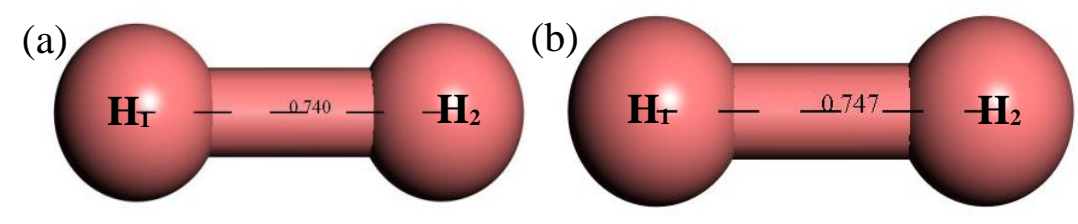

Figure 14. Molecular model of $\mathrm{H}_{2}$ molecule. (a) Initial model; (b) Optimized model. The unit of the angle in the image is $\left(^{\circ}\right)$, and the unit of the bond length is angstrom $(\AA)$.

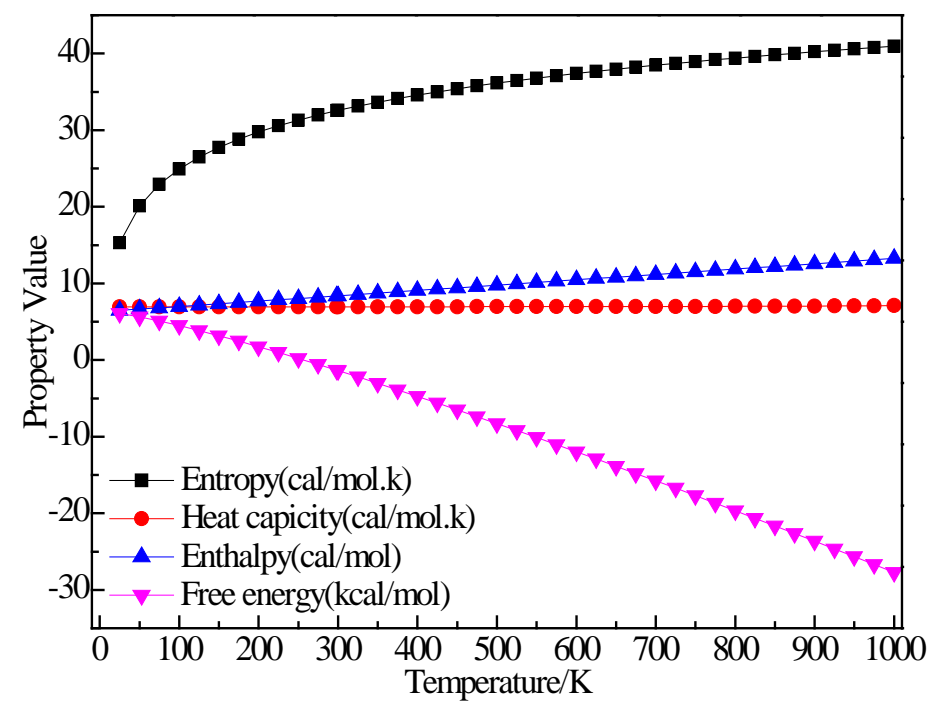

Figure 15. The relationship between the thermodynamic properties of $\mathrm{H}_{2}$ and temperature.

Table 5 shows the thermodynamic properties during the $\left(\mathrm{C}_{2} \mathrm{H}_{5}\right)_{3} \mathrm{Al}$ decomposition process (reaction Equation (4)). At $298.15 \mathrm{~K}$, the $\Delta \mathrm{H}$ was $-20.21 \mathrm{kcal} / \mathrm{mol}$, the $\Delta \mathrm{G}$ was $-54.822 \mathrm{kcal} / \mathrm{mol}$, the $\Delta \mathrm{S}$ was $116.08 \mathrm{cal} /(\mathrm{mol} \cdot \mathrm{K})$ (Table 6 ) and the enthalpy change was less than 0 , this was an endothermic reaction.

Table 6. The thermodynamic properties during preparing $\left(\mathrm{C}_{2} \mathrm{H}_{5}\right)_{3} \mathrm{Al}$ process.

\begin{tabular}{ccc}
\hline$\Delta \mathbf{H}(\mathrm{kcal} / \mathrm{mol})$ & $\Delta \mathrm{G}(\mathrm{kcal} / \mathrm{mol})$ & $\Delta \mathrm{S}(\mathrm{cal} / \mathrm{mol} \cdot \mathrm{K})$ \\
\hline-20.21 & -54.822 & 116.08 \\
\hline
\end{tabular}




\section{Conclusions}

We explored a novel chemical reduction of organic aluminum for plating $\mathrm{Al}$ on a graphene surface. The thermodynamics of the $\mathrm{Al}$ plating reaction process were studied. The $\mathrm{Al}$ plating process consisted of two stages: the first was to prepare $\left(\mathrm{C}_{2} \mathrm{H}_{5}\right)_{3} \mathrm{Al}$; the $\Delta \mathrm{H}$ was $10.64 \mathrm{kcal} / \mathrm{mol}$, the $\Delta \mathrm{G}$ was $19.87 \mathrm{kcal} / \mathrm{mol}$, the $\Delta \mathrm{S}$ was $30.9 \mathrm{cal} /(\mathrm{mol} \cdot \mathrm{K})$; this was an endothermic reaction. In the second stage, the $\left(\mathrm{C}_{2} \mathrm{H}_{5}\right)_{3} \mathrm{Al}$ decomposed into $\mathrm{Al}$ atoms, which were gradually deposited on the surface of the graphene and the Al plating formed. At $298.15 \mathrm{~K}$, the $\Delta \mathrm{H}$ was $-20.21 \mathrm{kcal} / \mathrm{mol}$, the $\Delta \mathrm{G}$ was $-54.822 \mathrm{kcal} / \mathrm{mol}$, the $\Delta \mathrm{S}$ was $116.08 \mathrm{cal} /(\mathrm{mol} \cdot \mathrm{K})$ and the enthalpy change was negative, thus indicating an endothermic reaction. The results show that the reaction efficiency can be improved significantly by increasing the reaction temperature and reaction time appropriately.

Author Contributions: Conceptualization, Z.Z.; Data curation, L.L., J.L. and P.H.; Formal analysis, Z.Z.; Investigation, L.L., J.L., L.W. and L.T.; Methodology, Z.Z.; Project administration, Peikang Bai; Software, P.H. and L.T.; Supervision, P.B.; Writing—original draft, Z.Z., L.L. and L.T.; Writing-review \& editing, L.L., J.L., L.W. and P.H.

Funding: This research was funded by the National Natural Science Foundation of China (Grant No. 51604246 and 51775521), Natural Science Foundation of Shanxi Province (Grant No. 201801D221154), the Major Science and Technology Projects of Shanxi Province, China (No. 20181101009) and the support of North University of China for Young Academic Leaders.

Conflicts of Interest: The authors declare no conflict of interest.

\section{References}

1. Boostani, A.F.; Yazdani, S.; Khosroshahi, R.A.; Jiang, Z.Y.; Wei, D. A novel graphene-stimulated semi-solid processing to fabricate advanced aluminium matrix nanocomposites. Mater. Sci. Eng. A 2018, 736, 316-322. [CrossRef]

2. Hu, Z.; Chen, F.; Xu, J.L.; Nian, Q.; Lin, D.; Chen, C.J.; Zhu, X.; Chen, Y.; Zhang, M. 3D printing graphene-aluminum nanocomposites. J. Alloys Compd. 2018, 746, 269-276. [CrossRef]

3. Wen, Z.Q.; Zhao, Y.H.; Li, H.J.; Zhang, Y.M.; Wang, S.; Hou, H. Theoretical Calculations of the Ideal Strength of $\mathrm{Ni}, \mathrm{NiAl}$ and $\mathrm{Ni}_{3} \mathrm{Al}$ in Tension and Shear. Sci. Adv. Mater. 2018, 10, 1420-1426. [CrossRef]

4. Jia, J.G.; Liu, D.Q.; Gao, C.Q.; Ji, G.S.; Guo, T.M. Preparation and mechanical properties of short carbon fibers reinforced alpha- $\mathrm{Al}_{2} \mathrm{O}_{3}$-based composites. Ceram. Int. 2018, 44, 19345-19351. [CrossRef]

5. Wang, X.W.; Zhu, X.J.; Gao, J.H.; Zheng, Z.Z.; Wang, H.J. Milling Research and Tool Selection Design of $\mathrm{SiC}_{14} \mathrm{Cu}_{4} \mathrm{Mg}_{0.5} \mathrm{Si}$ based on Aluminium Matrix 2A14. J. Wuhan Univ. Technol. 2018, 31, 1377-1380. [CrossRef]

6. Zhang, J.J.; Li, H.T.; Liu, H.; Wang, X.J.; Ma, Y.; Wang, N.; Umar, A.; Guo, Z.H. Determining Interfacial Shear Bond Strength in Thin Laminated Metal Composites. Sci. Adv. Mater. 2018, 10, 1543-1551. [CrossRef]

7. Zhao, Y.H.; Deng, S.J.; Liu, H.; Zhang, J.X.; Guo, Z.H.; Hou, H. First-principle investigation of pressure and temperature influence on structural, mechanical and thermodynamic properties of $\operatorname{Ti}(3) \mathrm{AC}(2)(\mathrm{A}=\mathrm{Al}$ and Si). Comput. Mater. Sci. 2018, 154, 365-370. [CrossRef]

8. Chen, G.; Chen, W.; Zhang, G.W.; Zheng, S.Q.; Zhang, Z.M. Microstructures and Mechanical Properties of Al-12Zn2.4Mg-1.2Cu Alloy under Different Deformation Ways. Rare Met. Mater. Eng. 2018, 45, 2237-2241.

9. Gao, X.; Yue, H.Y.; Guo, E.J.; Zhang, H.; Lin, X.Y.; Yao, L.H.; Wang, B. Preparation and tensile properties of homogeneously dispersed graphene reinforced aluminum matrix composites. Mater. Des. 2016, 94, 54-60. [CrossRef]

10. Zhao, M.; Xiong, D.B.; Tan, Z.Q.; Fan, G.L.; Guo, Q.; Guo, C.P.; Li, Z.Q.; Zhang, D. Lateral size effect of graphene on mechanical properties of aluminum matrix nanolaminated composites. Scr. Mater. 2017, 139, 44-48. [CrossRef]

11. Bagheri, P.; Farivar, M.; Simchi, A. Graphene-mediated self-assembly of gold nanorods into long fibers with controllable optical properties. Mater. Lett. 2018, 224, 13-17. [CrossRef]

12. Tsai, P.C.; Jeng, Y.R. Coalescence and epitaxial self-assembly of $\mathrm{Cu}$ nanoparticles on graphene surface: A molecular dynamics study. Comput. Mater. Sci. 2019, 156, 104-110. [CrossRef]

13. Muszynski, R.; Seger, B.; Kamat, P.V. Decorating Graphene Sheets with Gold Nanoparticles. J. Phys. Chem. C 2008, 112, 5263-5266. [CrossRef] 
14. Zhao, X.Y.; Tang, J.C.; Yu, F.X.; Ye, N. Preparation of graphene nanoplatelets reinforcing copper matrix composites by electrochemical deposition. J. Alloys Compd. 2018, 766, 266-273. [CrossRef]

15. Kim, Y.; Lee, J.; Yeom, M.S.; Shin, J.W.; Kim, H.; Cui, Y.; Kysar, J.W.; Hone, J.; Jung, Y.; Jeon, S.; Han, S.M. Strengthening effect of single-atomic-layer graphene in metal-graphene nanolayered composites. Nat. Commun. 2013, 4, 7. [CrossRef] [PubMed]

16. Li, N.; Zhang, L.; Xu, M.T.; Xia, T.; Ruan, X.W.; Song, S.; Ma, H.Z. Preparation and mechanical property of electrodeposited Al-graphene composite coating. Mater. Des. 2016, 111, 522-527. [CrossRef]

17. Zhao, Z.Y.; Li, L.; Bai, P.K.; Jin, Y.; Wu, L.Y.; Li, J.; Guan, R.G.; Qu, H.Q. The Heat Treatment Influence on the Microstructure and Hardness of TC4 Titanium Alloy Manufactured via Selective Laser Melting. Materials 2018, 11, 1318. [CrossRef]

18. Zhao, Z.Y.; Li, L.; Tan, L.; Bai, P.K.; Li, J.; Wu, L.Y.; Liao, H.H.; Cheng, Y.H. Simulation of Stress Field during the Selective Laser Melting Process of the Nickel-Based Superalloy, GH4169. Materials 2018, 11, 1525. [CrossRef]

19. Zhao, Z.Y.; Bai, P.K.; Guan, R.G.; Murugadoss, V.; Liu, H.; Wang, X.J.; Guo, Z. Microstructural evolution and mechanical strengthening mechanism of Mg-3Sn-1Mn-1La alloy after heat treatments. Mater. Sci. Eng. A 2018, 734, 200-209. [CrossRef]

20. Zhao, Z.Y.; Guan, R.G.; Zhang, J.H.; Zhao, Z.Y.; Bai, P.K. Effects of process parameters of semisolid stirring on microstructure of Mg-3Sn-1Mn-3SiC (wt\%) strip processed by rheo-rolling. Acta Metall. Sin. 2017, 30, 66-72. [CrossRef]

21. Cheng, P.; Zhao, Y.H.; Lu, R.P.; Hou, H. Effect of the morphology of long-period stacking ordered phase on mechanical properties and corrosion behavior of cast Mg-Zn-Y-Ti alloy. J. Alloys Compd. 2018, 764, 226-238. [CrossRef]

22. Zhang, Z.X.; Qu, S.J.; Feng, A.H.; Shen, J. Achieving grain refinement and enhanced mechanical properties in Ti-6Al-4V alloy produced by multidirectional isothermal forging. Mater. Sci. Eng. A 2017, 692, 127-138. [CrossRef]

23. Zhang, Z.X.; Qu, S.J.; Feng, A.H.; Shen, J.; Chen, D.L. Hot deformation behavior of Ti-6Al-4V alloy: Effect of initial microstructure. J. Alloys Compd. 2017, 718, 170-181. [CrossRef]

24. Zhang, Z.X.; Qu, S.J.; Feng, A.H.; Hu, X.; Shen, J. Microstructural mechanisms during multidirectional isothermal forging of as-cast Ti-6Al-4V alloy with an initial lamellar microstructure. J. Alloys Compd. 2019, 773, 277-287. [CrossRef]

25. Li, J.; Zhao, Z.Y.; Bai, P.K.; Qu, H.Q.; Liu, B.; Li, L.; Wu, L.Y.; Guan, R.G.; Liu, H.; Guo, Z.H. Microstructural evolution and mechanical properties of IN718 alloy fabricated by selective laser melting following different heat treatments. J. Alloys Compd. 2019, 772, 861-870. [CrossRef]

26. Zhao, Z.Y.; Misra, R.D.K.; Bai, P.K.; Gao, J.F.; Li, Y.J.; Guan, R.G.; Guo, Z.H.; Liu, H. Novel process of coating $\mathrm{Al}$ on graphene involving organic aluminum accompanying microstructure evolution. Mater. Lett. 2018, 232, 202-205. [CrossRef]

27. Lisovenko, A.S.; Morokuma, K.; Timoshkin, A.Y. Initial Gas Phase Reactions between $\mathrm{Al}\left(\mathrm{CH}_{3}\right)(3) / \mathrm{AIH}(3)$ and Ammonia: Theoretical Study. J. Phys. Chem. A 2015, 119, 744-751. [CrossRef] [PubMed]

28. Hou, H.; Wen, Z.Q.; Zhao, Y.H.; Fu, L.; Wang, N.; Han, P.D. First-principles investigations on structural, elastic, thermodynamic and electronic properties of $\mathrm{Ni}_{3} \mathrm{X}(\mathrm{X}=\mathrm{Al}, \mathrm{Ga}$ and $\mathrm{Ge})$ under pressure. Intermetallics 2014, 44, 110-115. [CrossRef]

29. Yang, X.M.; Hou, H.; Zhao, Y.H.; Yang, L.; Han, P.D. First-principles investigation of the structural, electronic and elastic properties of $\mathrm{Mg}_{x} \mathrm{Al}_{4-x} \mathrm{Sr}(\mathrm{X}=0,0.5,1)$ phases. Comp. Mater. Sci. 2014, 84, 374-380. [CrossRef]

30. dos Santos, R.B.; Rivelino, R.; de Brito Mota, F.; Gueorguiev, G.K.; Kakanakova-Georgieva, A. Dopant species with Al-Si and N-Si bonding in the MOCVD of AlN implementing trimethylaluminum, ammonia and silane. J. Phys. D Appl. Phys. 2015, 48, 295104. [CrossRef]

31. Freitas, R.R.Q.; Gueorguiev, G.K.; de Brito Mota, F.; de Castilho, C.M.C.; Stafstrom, S.; Kakanakova-Georgieva, A. Reactivity of adducts relevant to the deposition of hexagonal BN from first-principles calculations. Chem. Phys. Lett. 2013, 583, 119-124. [CrossRef]

32. Inagaki, Y.; Kozawa, T. Chemical Reaction Pathways for MOVPE Growth of Aluminum Nitride. ECS J. Solid State Sci. Technol. 2016, 5, 73-75. [CrossRef] 
33. Sangiovanni, D.G.; Gueorguiev, G.K.; Kakanakova-Georgieva, A. Ab initio molecular dynamics of atomic-scale surface reactions: Insights into metal organic chemical vapor deposition of AlN on grapheme. Phys. Chem. Chem. Phys. 2018, 20, 17751-17761. [CrossRef] [PubMed]

34. Sadhukhan, T.; Samanta, B.; Ansari, S.A.; Pal, S. Theoretical study of C-X $[\mathrm{X}=\mathrm{Cl}$, Br] bond activation on aluminum nanoclusters. Theor. Chem. Acc. 2016, 135, 234. [CrossRef] 